\title{
Prevalence of ehrlichial infection among dogs and ticks in Northeastern Brazil
}

\author{
Prevalência da infecção por Ehrlichia em cães e carrapatos no Nordeste do Brasil \\ Bárbara Maria Paraná da Silva Souza ${ }^{1}$; Danielle Custódio Leal ${ }^{1}$; Débora Cristina Portela Medina Barboza ${ }^{1}$; \\ Rosângela Soares Uzêda²; Adriano Costa De Alcântara'; Fernando Ferreira³; Marcelo Bahia Labruna; \\ Luís Fernando Pita Gondim²; Carlos Roberto Franke ${ }^{1 *}$
}

\begin{abstract}
${ }^{1}$ Laboratório de Infectologia Veterinária - LIVE, Departamento de Produçáo Animal, Escola de Medicina Veterinária, Universidade Federal da Bahia - UFBA

${ }^{2}$ Laboratório de Diagnóstico de Parasitoses, Departamento de Patologia e Clínicas, Escola de Medicina Veterinária, Universidade Federal da Bahia - UFBA

${ }^{3}$ Departamento de Medicina Veterinária e Preventiva e Saúde Animal, Faculdade de Medicina Veterinária e Zootecnia, Universidade de São Paulo - USP
\end{abstract}

Received December 11, 2009

Accepted January 29, 2010

\begin{abstract}
This study investigated the epidemiology of canine ehrlichiosis in Northeastern Brazil, focusing the identification of the Ehrlichia species and vectors involved. Samples were collected from 472 domestic dogs residing in the health districts of Cajazeiras and Itapuã of Salvador city. The average prevalence of antibodies reactive to $E$. canis by immunofluorescent antibody test (IFAT) (titer $\geq 1: 80$ ) was $35.6 \%$ (168/472). Blood samples from the E. canis-seropositive animals were tested by nested PCR in order to identify the Ehrlichia species responsible for the infection. Among the seropositives, 58 (34.5\%) were found to be PCR-positive for E. canis. Ticks were found in 32 dogs. Nested-PCR analysis showed that $21.9 \%$ (7/32) of the Rhipicephalus sanguineus were infected by E. canis. In both dogs and Rhipicephalus sanguineus, nested-PCR for $E$. ewingii and E. chaffeensis was negative, with no amplification of DNA fragment.
\end{abstract}

Keywords: Ehrlichia, PCR, epidemiology.

\section{Resumo}

Este estudo objetivou pesquisar a epidemiologia da erliquiose canina no Nordeste do Brasil, com especial atenção na identificação da espécie de Ehrlichia envolvida nas infecçóes caninas e vetoriais detectadas. Para isso foram coletadas amostras de 472 cáes domiciliados nos distritos sanitários de Cajazeiras e Itapuã. A prevalência de anticorpos anti-E. canis, pela imunofluorescência indireta (título $\geq 1: 80$ ), em cáes foi de 35,6\% (168/472). Os animais soropositivos foram analisados por uma nested-PCR para identificaçáo da espécie de Ehrlichia responsável pela infecção. Dentre os positivos, $58(34,5 \%)$ cáes foram PCR-positivos para E. canis. Foram coletados e classificados os carrapatos em 32 cáes. A nested-PCR de Rhipicephalus sanguineus resultou em 21,9\% (7/32) de infecçáo por E. canis. A nested-PCR de amostras de sangue de cães e Rhipicephalus sanguineus para E. chaffeensis e E. ewingii foi negativa, não havendo amplificação de fragmento de DNA.

Palavras-chaves: Ehrlichia, PCR, epidemiologia.

\section{Introduction}

Canine ehrlichiosis is a tick-borne disease caused by an obligatory intracellular Gram-negative bacteria of mononuclear cells (MURPHY et al., 1998; SKOTARCZACK, 2003). Considered one of the most important infectious diseases among dogs, canine ehrlichiosis arises via Ixodidae vectors, which depend on hosts that are vulnerable to the infection as well as being climate-related.

${ }^{*}$ Corresponding author: Carlos Roberto Franke Laboratório de Infectologia Veterinária - LIVE,

Departamento de Produçáo Animal, Escola de Medicina Veterinária,

Universidade Federal da Bahia - UFBA, Salvador - BA, Brazil;

e-mail: franke@ufba.br; Supported by: FAPESB
Species of the genus Ehrlichia such as E. canis, E. chaffeensis, and E. ewingii are responsible for disease in dogs and humans (DUMLER et al., 2001). Traditionally, both Ehrlichia canis and E. ewingii are involved in canine infections, but only the first has worldwide distribution, a reflection of the primary vector, Rhipicephalus sanguineus (RIKIHISA, 1991; BREITSCHWERDT; HEGARTY; HANCOCK, 1998a; DUMLER et al., 2001). E. ewingii is limited to the United States, but has been identified in Amblyomma americanum, Rhipicephalus sanguineus, and Dermacentor variabilis ticks (MURPHY et al., 1998), making its distribution potentially similar to that of these vectors. The main vector of $E$. chaffeensis 
is $A$. americanum, although infection is also known to occur in $D$. variabilis and $R$. sanguineus (WALKER et al., 2004; NDIP et al., 2007; RIKIHISA, 1999; STANDAERT et al., 2000).

In Brazil, E. canis is the only ehrlichial agent reported to infect dogs. A new subspecies of Ehrlichia canis, recently characterized in Venezuela, underscored the zoonotic potential of this genre, in view of identifying persistent and asymptomatic infection in a human patient with involvement of a dog and also ticks infected by the same microorganism (PEREZ; RIKIHISA; WEN, 1996; PEREZ et al., 2006; UNVER et al., 2001). DNA of E. chaffeensis has also been detected in members of the Cervidae family (Blastocerus dichotomus) captured in the area of the Paraná River in southeastern São Paulo and eastern Mato Grosso do Sul, Brazil (MACHADO et al., 2006). The main hypothesis of the present study is that E. chaffeensis and E. ewingii, as well as E. canis, can infect dogs in Brazil and are possibly undiagnosed in most commercial serologic tests. The reason for this hypothesis is that $R$. sanguineus, which is widely distributed in Brazil, may potentially transmit E. chaffeensis and E. ewingii to dogs (NDIP et al., 2007). The study therefore aimed to identify the species of Ehrlichia sp (E. canis, E. chaffeensis and $E$. ewingii) present in canine and tick vectors in two of the city's sanitary districts.

\section{Material and Methods}

\section{Area of study}

The study was carried out in the city of Salvador, Bahia $\left(12^{\circ} 58^{\prime} 16^{\prime \prime} \mathrm{S}\right.$ and $\left.38^{\circ} 30^{\prime} 39^{\prime \prime} \mathrm{W}\right)$, focusing on the sanitary districts of Itapuã and Cajazeiras. The city's health administration divides the urban area into 12 sanitary districts, each of which includes a number of different neighborhoods (Figure 1). The city has a geographic area of $707 \mathrm{~km}^{2}$ (considered 100\% urban) and a population of 2,443,107 (BRASIL, 2000).

\section{Blood collection and canine ticks}

Canine blood samples and ticks were collected during the year of 2006. Only one dog per household was included in the study. Approximately $4 \mathrm{~mL}$ of blood was collected from each dog by venopunction of the cephalic or jugular veins. Approximately $3 \mathrm{~mL}$ of this blood was stored in tubes without anti-coagulant for later processing in serological tests and the rest was stored in sterile $1.5 \mathrm{~mL}$ tubes containing the anti-coagulant EDTA (ethylenodiamine tetra-acidic acid) for molecular analysis. The blood and serum samples were stored at $-20^{\circ} \mathrm{C}$. When dogs were infested by ticks, parasite specimens were removed and stored at $-20^{\circ} \mathrm{C}$, pending extraction of their DNA.

\section{Immunofluorescent antibody test}

In order to obtain the antigen, E. canis (strain: Scott) (AGUIAR et al., 2007a; AGUIAR; HAGIWARA; LABRUNA, 2008) was cultivated in malignant canine cells (line DH82), maintained in the medium Dulbecco's Modified Eagle's (Sigma Aldrich, USA) with the addition of 5\% Bovine Calf Serum (Hyclone, USA), in an environment with $5 \% \mathrm{CO}_{2}$ and a temperature of $37{ }^{\circ} \mathrm{C}$, according to Aguiar et al. (2007a). For the immunofluorescent antibody test (IFAT), a dilution of 1:80 in PBS with $0.5 \%$ of bovine serum albumin was employed as a cut-off. A commercial fluorescein-labeled anti-canine IgG (Sigma Aldrich, USA) was used as a secondary antibody. Reactions were performed as previously described (AGUIAR et al., 2007a). Slides were observed using an ultraviolet microscope (Immuno-Cell, Belgium) at $400 \times$ magnification.

\section{Extraction of DNA from blood and tick samples}

Blood samples from dogs that were soropositive for E. canis were submitted to DNA extraction using a commercial kit (Wizard ${ }^{\circledR}$ Genomic DNA Purification Kit, Promega, Madison, USA), as described by the manufacturer. Ticks collected from dogs were classified according to species and submitted to DNA extraction using the proteinase K-phenol/chloroform method, as follows: ticks were washed twice in PBS, crushed in liquid nitrogen, re-suspended in TE $10 \mathrm{mM}$ (Tris and $1 \mathrm{mM}$ EDTA) containing 1\% Dodecil sodium sulfate (SDS) and $100 \mu \mathrm{g} \cdot \mathrm{mL}^{-1}$ of proteinase $\mathrm{K}$, and maintained at a temperature of $56^{\circ} \mathrm{C}$ for 16 hours (overnight). The samples were then heated to $100{ }^{\circ} \mathrm{C}$ for 15 minutes, in order to de-activate the proteinase $\mathrm{K}$. Following this, the samples were submitted to phenol extraction: chloroform:isoamylic alcohol (25:24:1) followed by chloroform:isoamylic alcohol (24:1) two times, to remove phenol residues. The DNA was then precipitated with two volumes of $100 \%$ ethanol and $1 / 103 \mathrm{M}$ sodium acetate $(\mathrm{pH}=5.2)$, to a temperature of $-20{ }^{\circ} \mathrm{C}$, and then washed twice in $70 \%$ ethanol. After this, the DNA was re-suspended in $50 \mu \mathrm{L} \mathrm{TE}$ (SAMBROOK, FRITCH, MANIATIS, 2001).

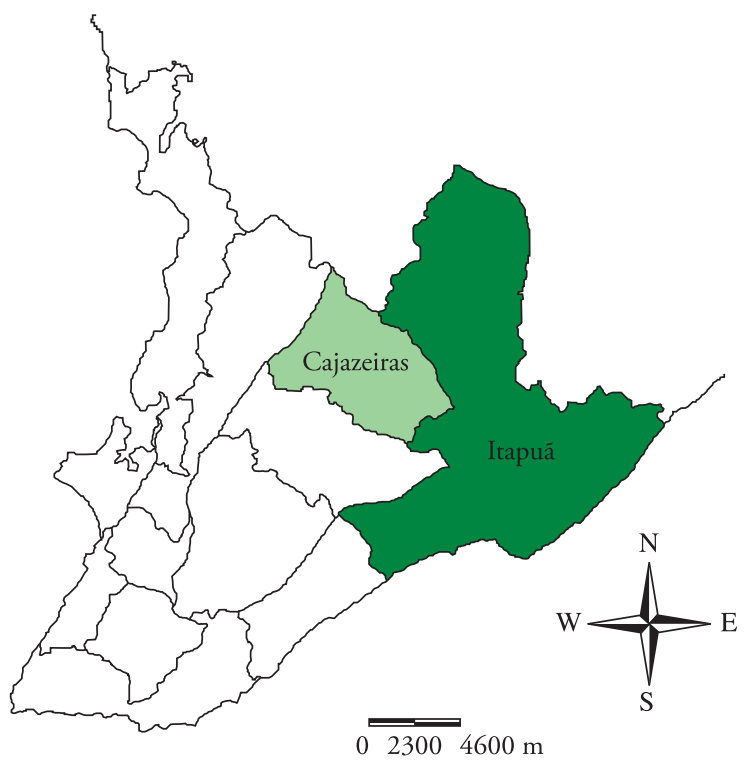

Figure 1. Map of the city of Salvador, Bahia, showing its 12 sanitary districts. Colored regions represent the two districts included in the study. 


\section{Nested-PCR}

Amplification of ehrlichial DNA was attempted by nested-PCR with canine and tick DNA samples in accordance with the technique described by Murphy et al. (1998). This PCR protocol consists of a general primary reaction, and nested reactions, each specific for a Ehrlichia species (E. canis, E. chaffeensis, or E. ewingii) with primers that amplify a fragment $398 \mathrm{pb}$ of the $16 \mathrm{~S}$ rRNA gene. Primers ECC (5'-AGA ACG AAC GCT GGC GGC AAG C-3') and ECB (5'-CGT ATT ACC GCG GCT GCT GGC A- 30) amplify all Ehrlichia spp. Primers HE1 (5'-CAA TTG CTT ATA ACC TTT TGG TTA TAA AT-3') and HE3 (5'-TAT AGG TAC CGT CAT TAT CTT CCC TAT- $3^{\prime}$ ) were used for E. chaffeensisspecific amplifications, primers ECAN5 (5'- CAA TTA TTT ATA GCC TCT GGC TAT AGG A-3') and HE3 were used for E. canis-specific amplifications, and primers EE52 (5'-CGA ACA ATT CCT AAA TAG TCT CTG AC-3') and HE3 were used for E. ewingii-specific amplifications. For E. canis and E. chaffeensis, positive controls came from DH82 infected cell cultures and for E. ewingii, from infected animals. PCR products were observed and photographed in agarose gel at 1.5\% containing green SYBR (Molecular Probes, Invitrogen, USA) diluted 10,000 times in 0.5X TBE buffer $(0.045 \mathrm{M}$ Tri-borate and $1 \mathrm{mM}$ EDTA, $\mathrm{pH}=8.3)$.

\section{Animals and statistical analysis}

According to data provided by the pest control agency of the city government, in 2005 there were 334,195 domestic dogs living within the urban area, with 26,095 of these residing in the sanitary district of Itapuã and another 20,370 in Cajazeiras. For the purposes of this study, the sample size was defined as $1 \%$ of the canine population of each of these two sanitary districts: 203 animals in the district of Cajazeiras and 260 in that of Itapuá. However, nine extra samples were collected from the Itapuá district, totaling 472 .

From the size of the sample, the number of clusters to be sampled was given, and, in the case of this study, the units of area to be investigated were the census tracts used by the Brasil, (2000). The number of census tracts was determined using the Equation 1 proposed by Thrusfield (1995), described below, with the following parameters: confidence interval of $95 \%$, expected prevalence of $1 \%$, precision of $1 \%$, and variation among clusters estimated at $0.5 \%$.

$$
g=\frac{1.96^{2} \times T_{s} \times V_{c}}{d^{2} \times T_{s}-1.96^{2} \times P_{\text {esp }} \times\left(1-P_{\text {esp }}\right)}
$$

with:

g: number of clusters to be sampled

$\mathrm{P}_{\text {esp }}$ : expected prevalence

$\mathrm{d}$ : desired precision

$\mathrm{T}$ : total number of animals to be sampled

$\mathrm{V}_{c}$ : variation among clusters

The Minitab statistics software was used in calculating the sampling of the survey and in drawing the canine census investigated in this study.

\section{Results}

The overall prevalence of dogs seropositive to $E$. canis was $35.6 \%$ (168/472), with $41.4 \%(84 / 203)$ in the district of Cajazeiras and $31.2 \%(84 / 269)$ in Itapuã. Of the 79 census tracts investigated, only 11 had no dogs that tested positive for E. canis. Of these, $17.1 \%$ $(6 / 35)$ were in Cajazeiras and $11.4 \%(5 / 44)$ were in Itapuá.

Among seropositive samples $(\mathrm{n}=168)$, the nested-PCR test for E. canis, E. chaffeensis, and E. ewingii revealed a positivity of $34.5 \%$ (58/168) for $E$. canis. None of the soropositive animals tested positive for E. chaffeensis or E. ewingii.

Ticks were collected from 32 dogs. All of the specimens obtained belonged to the species Rhipicephalus sanguineus and were at different stages of the life cycle. Eighteen of the dogs from which ticks were collected proved to be soronegative (Table 1). Fourteen were soropositive, with three of these also being PCR-positive for E. canis. In $21.9 \%$ (7/32) of the tick specimens, infection by E. canis was detected via nested-PCR. Of the seven ticks that were PCR-positive, two were collected from soronegative dogs, and five from PCR-positive dogs. In none of the tick specimens did nested-PCR with specific primers for the DNA of E. chaffeensis and E. ewingii produce amplicons.

\section{Discussion}

This study demonstrates the presence of antibodies against E. canis in dogs from Salvador, Bahia, with similar results to other Brazilian studies. In the Monte Negro district of the State of Roraima, utilizing a randomly-selected sample of the urban area, Aguiar et al. (2007b) obtained a prevalence rate of 37.9\% (58/153) similar to the one observed in the present study. In another study, conducted by Carlos et al. (2007) in two cities in the Southwestern region of the State of Bahia, Itabuna and Ilhéus, the infection rate was $36 \%(72 / 200)$, also similar to that of the present study; it should be noted, however, that the dogs in the study by Carlos et al. were chosen from animals receiving clinical care. In Brazil, the prevalence of canine ehrlichiosis differs between the Brazilian States, ranging from 14 to 44.7\% (MOREIRA et al., 2003; BULLA et al., 2004; DAGNONE et al., 2003; MACIEIRA et al., 2005; COSTA Jr. et al., 2007; TRAPP et al., 2006; ALBERNAZ et al., 2007; SANTOS et al., 2007). This variation can be attributed to the diversity of experimental designs and diagnostic protocols used by the authors, and environmental factors involved in the epidemiology of ehrlichiosis in the regions studied. Previous studies, conducted among dogs treated in clinics and veterinary hospitals in Cameroon and the United States, have demonstrated soroprevalence rates for E. canis of 32 and 76\% (WEN et al., 1997; NDIP et al., 2005). The differences observed in the canine soropositivity frequency rates among the various studies may be attributed, among other factors, to the cut-off utilized in the IFAT in each study (varying from 1:20 to 1:64).

E. canis infection, confirmed by nested-PCR in soropositive dogs, was detected in $34.5 \%$ (58/168) of the E. canis-seropositive animals examined in the present study. In Cameroon and the United States, infection confirmed by PCR was obtained in $41 \%$ of the dogs that tested positive via IFAT (WEN et al., 1997; NDIP et al., 2007). 
Table 1. Correlation results of nested-PCR in ticks and serology for ehrlichiosis in dogs.

\begin{tabular}{ccc}
\hline Ticks & \multicolumn{2}{c}{ Dogs } \\
\hline Nested-PCR & \multicolumn{3}{c}{ IFI } \\
\cline { 2 - 3 } & Positive & Negative \\
\hline Positive & 5 & 2 \\
Negative & 9 & 16 \\
\hline Total & 14 & 18 \\
\hline
\end{tabular}

Some authors have argued for the utilization of a combination of IFAT and PCR in diagnosing canine ehrlichiosis, pointing out that these tests are more sensitive and are able to detect the infection in different stages (IQBAL; CHAICHANASIRIWITHAYA; RIKIHISA, 1994; WEN et al., 1997).

The difference in the number of soropositive dogs and the number in which infection was confirmed by PCR has two possible explanations. First, considering that Ehrlichia sp is endemic in Salvador and that infected animals do not usually present clinical signs of the disease, some of the positive animals may have evolved towards a cure while still having detectable amounts of anti-E. canis antibodies (CODNER; FARRIS-SMITH, 1986; HARRUS et al., 1998a; SKOTARCZACK, 2003). Secondly, considering that the nested-PCR technique utilized in this study is highly sensitive and specific (WEN et al., 1997; MURPHY et al., 1998), the test's capacity to detect the presence of Ehrlichia DNA in soropositive dogs will depend on the type of sample collected for the test. In the acute phase, Ehrlichia can be easily detected in blood, while in subclinical and chronic phases, the tissues most appropriate for sampling are the spleen and bone marrow, respectively (HARRUS et al., 1998a,b; HARRUS et al., 2004; MYLONAKIS et al., 2004). Considering that in the present study only blood samples were utilized for nested-PCR, it is possible that dogs in subclinical and chronic clinical phases could not be correctly diagnosed.

All ticks collected in the present study belonged to the species $R$. sanguineus and were parasitizing the dogs at the time of collection. There are scarce data available regarding $E$. canis infection in R. sanguineus (MURPHY et al., 1998; UNVER et al., 2001; NDIP et al., 2007). In the study performed by Aguiar et al. (2007b) in Monte Negro (State of Rondônia) and Sáo Paulo (State of São Paulo), E. canis-infection rates in $R$. sanguineus ticks varied from $2.4(4 / 165)$ to $6.2 \%(10 / 162)$. Results similar to those obtained in the present study were observed in Africa, where the infection rate was $21 \%$ (19/92), with the tick specimens examined having been collected from 15 dogs (NDIP et al., 2007). The infection rate for ticks found in the present study suggests intense infection in the populations studied, pointing to the need for further studies involving larger samples of the vector, taking into account seasonal variations as well as specific details about the clinical stage of the disease in the dogs examined.

E. chaffeensis and E. ewingii infections were not detected in any of the dogs and ticks sampled in the present study. Similarly, in a study conducted in Sáo Paulo among dogs under clinical suspicion for tick-transmitted diseases ( $\mathrm{n}=198$ ), neither of these Ehrlichia species were detected (DINIZ et al., 2007). On the other hand, it should be noted that E. chaffeensis has been found to infect Cervidae in Brazil (MACHADO et al., 2006), and that in the West African country of Cameroon, E. chaffeensis and E. ewingii have been reported in $R$. sanguineus (NDIP et al., 2007).

In the present study $E$. chaffeensis and $E$. ewingii were not detected in either dogs or ticks. Further studies seeking to monitor canine ehrlichiosis should include molecular analysis of tissues other than blood, in order to increase the possibility of detecting E. chaffeensis and E. ewingii.

\section{Conflict of Interest Statement}

None of the authors of this paper has a financial or personal relationship with other people or organizations that could inappropriately influence or bias the content of the paper.

\section{Acknowledgments}

The authors wish to thank the Fundação de Amparo à Pesquisa do Estado da Bahia (FAPESB), which provided financial support to this project; Dr. Susan Little (Oklahoma State University) for donation the ADN of E. chaffeensis and E. ewingii; the Secretaria de Saúde of the State of Bahia (SESAB) and the Center for Pest Control of the city of Salvador (CCZ) for technical support and epidemiological data provided during the study; and the Alexander von Humboldt Foundation, for molecular biology equipment donated to Dr. Carlos Roberto Franke (III-ERSX-BRA/1067633).

\section{References}

AGUIAR, D. M. et al. Diagnóstico sorológico de erliquiose canina com antígeno brasileiro de Ehrlichia canis. Ciência Rural, v. 37, n. 3, p. 796-802, 2007a.

AGUIAR, D. M. et al. Prevalence of Ehrlichia canis (Rickettsiales: Anaplasmataceae) in Dogs and Rhipicephalus sanguineus (Acari: Ixodidae) Ticks from Brazil. Vector-borne Diseases, Surveillance, Prevention, v. 44, n. 1, p. 126-132, 2007 b.

AGUIAR, D. M; HAGIWARA, M. K; LABRUNA, M. B. In Vitro isolation and molecular characterization of an Ehrlichia canis strain from São Paulo, Brazil. Brazilian Journal of Microbiology, v. 39, p. 489-493, 2008.

ALBERNAZ, A. P. et al. Erliquiose canina em Campos dos Goytacazes, Rio de Janeiro, Brasil. Ciência Animal Brasileira, v. 8, n. 4, p. 799-806, 2007.

BRASIL Ministério do Planejamento, Orçamento e Gestão. Instituto Brasileiro de Geografia e Estatística - IBGE. Censo demográfico. Brasília, 2000.

BREITSCHWERDT, E. B; HEGARTY, B. C.; HANCOCK, S. I. Sequential evaluation of dogs naturally infected with Ehrlichia canis, Ehrlichia chaffeensis, Ehrlichia equi, Ehrlichia ewingii, or Bartonella vinsonii. Journal of Clinical Microbiology, v. 36, n. 9, p. 2645-2651, 1998. 
BULLA, C. et al. The relationship between the degree of thrombocytopenia and infection with Ehrlichia canis in an endemic area. Veterinary Research, v. 35, p. 141-146. 2004.

CARLOS, R. S. A. et al. Frequência de anticorpos anti-Erhlichia canis, Borrelia burgdorferi e antígenos de Dirofilaria immitis em cães na microrregião Ilhéus-Itabuna, Bahia, Brasil. Revista Brasileira de Parasitologia Veterinaria, v. 16, n. 3, p. 117-120, 2007.

CODNER, E. C.; FARRIS-SMITH, L. L. Characterization of the subclinical phase of ehrlichiosis in dogs. Journal of the American Veterinary Medical Association, v. 189, n. 1, p. 47-50, 1986.

COSTA Jr, L. M. et al. Sero-prevalence and risk indicators for canine ehrlichiosis in three rural areas of Brazil. The Veterinary Journal, v. 174, n. 3, p. 673-676, 2007.

DAGNONE, A. S. et al. Ehrlichiosis in anemic, thrombocytopenic, or tick-infested dogs from a hospital population in South Brazil. Veterinary Parasitology, v. 117, n. 4, p. 285-290, 2003.

DINIZ, P. P. V. P. et al. Surveillance for Zoonotic Vector-Borne Infections Using Sick Dogs from Southeastern Brazil. Vector-Borne and Zoonotic Diseases, v. 7, n. 4, p. 689- 697, 2007.

DUMLER, J. S. et al. Reorganization of genera in the families Rickettsiaceae and Anaplasmataceae in the order Rickettsiales: unification of some species of Ehrlichia with Anaplasma, Cowdria with Ehrlichia and Ehrlichia with Neorickettsia, descriptions of six new species combinations and designation of Ehrlichia equi and "HGE agent" as subjective synonyms of Ehrlichia phagocytophila. International Journal of Systematic and Evolutionary Microbilogy, v. 51, n. 666, p. 2145-2165, 2001.

HARRUS, S. et al. Amplification of ehrlichial DNA from dogs 34 months after infection with Ehrlichia canis. Journal of Clinical Microbiology, v. 36, n. 1, p. 73-76, 1998 b.

HARRUS, S. et al. Comparison of simultaneous splenic sample PCR with blood sample PCR for diagnosis and treatment of experimental Ehrlichia canis infection. Antimicrobial Agents and Chemotherapy, v. 48, n. 11, p. 4488-4490, 2004.

HARRUS, S. et al. Investigation of splenic functions in canine monocytic ehrlichiosis. Veterinary Immunology and Immunopathology, v. 62, n. 1 , p. 15-27, 1998a.

IQBAL, Z; CHAICHANASIRIWITHAYA, W; RIKIHISA, Y. Comparison of PCR with other tests for early diagnosis of canine ehrlichiosis. Journal of Clinical Microbiology, v. 32,n. 7, p. 1658-1662, 1994.

MACHADO, R. Z. et al. Detection of Ehrlichia chaffeensis in Brazilian marsh deer (Blastocerus dichotomus). Veterinary Parasitology, v. 139, n. 1-3, p. 262-266, 2006.

MACIEIRA, D. B. et al. Prevalence of Ehrlichia canis infection in thrombocytopenic dogs from Rio de Janeiro, Brazil. Veterinary Clinical Pathology, v. 34, n. 1, p. 44-48, 2005.

MOREIRA, S. M. et al. Retrospective study (1998-2001) on canine ehrlichiosis in Belo Horizonte, MG, Brazil. Arquivo Brasileiro de Medicina Veterinária e Zootecnia, v. 55, n. 2, p. 141-147, 2003.
MURPHY, G.L. et al. A molecular and serologic survey of Ehrlichia canis, E. chaffeensis and E. ewingii in dogs and ticks from Oklahoma. Veterinary Parasitology, v. 79,n. 4, p. 325-339, 1998.

MYLONAKIS, M. E. et al. Chronic canine ehrlichiosis (Ehrlichia canis): a retrospective study of 19 natural cases. Journal of the American Animal Hospital Association, v. 40, n. 3, p. 174-184, 2004.

NDIP, L. M. et al. Ehrlichia Species in Rhipicephalus sanguineus Ticks in Cameroon. Vector-Borne and Zoonotic Disease, v. 7, n. 2, p. 221-227, 2007.

NDIP, L. M. et al. Ehrlichial infection in Cameroonian canines by Ehrlichia canis and Ehrlichia ewingii. Veterinary Microbiology, v. 111, n. 1-2, p. 59-66, 2005.

PEREZ, M. et al. Human infection with Ehrlichia canis accompanied by clinical signs in Venezuela. Annals New York. Academy Science, v. 1078, p. 110-117, 2006.

PEREZ, M.; RIKIHISA,Y.; WEN, B. Ehrlichia canis- Like agent isolated from a man in Venezuela: antigenic and genetic characterization. Journal Clinical Microbiology, v. 34, n. 9, p. 2133-2139, 1996.

RIKIHISA, Y. Clinical and biological aspects of infection caused by Ehrlichia chaffeensis. Microbes and Infection, v. 1, n. 5, p. 367-376, 1999.

RIKIHISA, Y. The tribe Ehrlichieae and ehrlichial diseases. Clinical Microbiology Reviews, v. 4, n. 3, p. 286-308, 1991.

SAMBROOK, J.; FRITCH, E. F.; MANIATIS, T. Molecular cloning: a laboratory manual. 3. ed. New York: Cold Spring Harbor, 1991.

SANTOS, F. et al. Molecular evaluation of the incidence of Ehrlichia canis, Anaplasma platys and Babesia spp. in dogs from Ribeirão Preto, Brazil. Veterinary Journal, v. 179, n. 1, p. 145-148, 2007.

STANDAERT, S. M. et al. Primary Isolation of Ehrlichia chaffeensis from Patients with Febrile Illnesses: Clinical and Molecular Characteristics. The Journal of Infectious Diseases, v.181, n. 3, p. 1082-1088, 2000.

THRUSFIELD, M. Veterinary epidemiology. Cambrige: Black-Weel Science, 1995. 479 p.

TRAPP, S. M. et al. Seroepidemiology of canine babesiosis and ehrlichiosis in a hospital population. Veterinary Parasitology, v. 140, n. 3-4, p. 223-230, 2006.

UNVER, A. et al. Molecular and antigenic comparison of Ehrlichia canis isolates from dogs, ticks, and a human in Venezuela. Journal of Clinical Microbiology, v. 39, n. 8, p. 2788-2793, 2001.

WALKER D.H. et al. Ehrlichia chaffeensis: a prevalent, life-threatening, emerging pathogen. Transactions of the American Clinical and Climatological Association, v. 115, p. 375-384, 2004.

WEN, B. et al. Comparison of Nested PCR with immunofluorescent-antibody assay for detection of Ehrlichia canis infection in dogs treated with doxycycline. Journal of Clinical Microbiology, v. 35, n. 7, p. 1852-1855, 1997. 